\title{
Triangular Attitude of Patriarchy:
}

\section{A Major Issue of Lifelong Learning among Women in India}

\author{
Navnath B. Tupe ${ }^{1}$ \\ ${ }^{1}$ Department of Adult, Continuing Education and Extension, SP Pune University, India \\ Correspondence: Navnath B. Tupe, Department of Adult, Continuing Education and Extension, SP Pune University, \\ India. E-mail: navnathtupe@unipune.ac.in
}

Received: October 18, 2014

Accepted: November 13, 2014

Online Published: November 14, 2014

doi:10.5430/bmr.v3n4p11

URL: http://dx.doi.org/10.5430/bmr.v3n4p11

\begin{abstract}
The purpose of this research is to develop a deeper understanding of the socio-economic and gender issues with special reference to Lifelong Learning. The socio-economic and gender issue is described in terms of triangular attitude of patriarchy which includes negligence towards women, discriminatory expectancy and deprivation of resources. These are the three dimensions of patriarchic attitude that creates the threats in empowerment of women which was the priori theme of this research. The comparison between the rural and urban issues of housewives, member of self-help groups and women entrepreneurs has been studied. It is another interesting aspect of this study. This survey is significance to several audiences including rural \& urban community leaders, adult educators, programme developers, researchers, social reformers, bankers, policymakers, NGOs and for government agencies. Rural and urban community leaders may derive ideas and issues that will help them promote lifelong learning as an approach for community economic and social development and for bridging the gender gaps. Adult educators and programme developers may be encouraged to consider sociocultural learning theory and approaches to address the issues about resources, expectancy and negligence.
\end{abstract}

Keywords: Triangular Attitude of patriarchy (TAP), Lifelong Learning (LLL), negligence towards women, discriminatory expectancy and deprivation of resources, Self Help Group (SHG)

\section{Introduction}

In India, illiteracy and poverty both are major issues among women. Education alone would not solve the problem of poverty, but poverty cannot be eradicated without education. It is necessary to eradicate poverty in order to promote learning. LLL can generate employment and help to solve the problem of unemployment and bridge the gender gaps. Ultimately Education is seen as a means to attain socio- economic equality. It can increase productivity, employment growth and living standards. Economic growth should result from a suitable combination of employment growth and growth in productivity. Skilled and trained labour-force is essential to promote the entrepreneurships and productivity growth with quality. It implies that employment -oriented growth in a country like India would move, of necessity, to be at high rate.

Human capital theory suggests that investment in education in later life should have productivity and wage gain. In this context Biesta emphasized that,

"We can see that in more recent approaches the economic function of lifelong learning has taken central position, and we might even say that in the current scheme economic growth has become an intrinsic value: it is desired for its own sake, not in order to achieve something else(Biesta, 2006)."

Economic growth is generally failed to stake a desirable balance between growth of productivity and employment. The main problem explored in this research is, whether the "Triangular Attitude of Patriarchy" (TAP) is a barrier in LLL of women? This research paper explains that, how TAP creates barriers in lifetime learning of women. This is the central question of this research. The primary and secondary data resources were aimed at collectively answering the central research question of the present study. The exploration of the reality of LLL of women was based on the following set of sub questions. What is the situation of LLL of rural women as compare to urban women? What are the socio-economic and gender issues in LLL of rural women as compare to urban women? 


\section{Triangular Attitudes of Patriarchy}

In Indian societies, male is not only center of the family but he is also powerful and dominant element in overall society. He has the authority to control to female and having right to use the resources as per his choices and desires. Compared with women, men have more rights to use resources as per their choice. According to the researcher, this gender biasness arises to the three main reasons illustrated in the diagram of TAP.

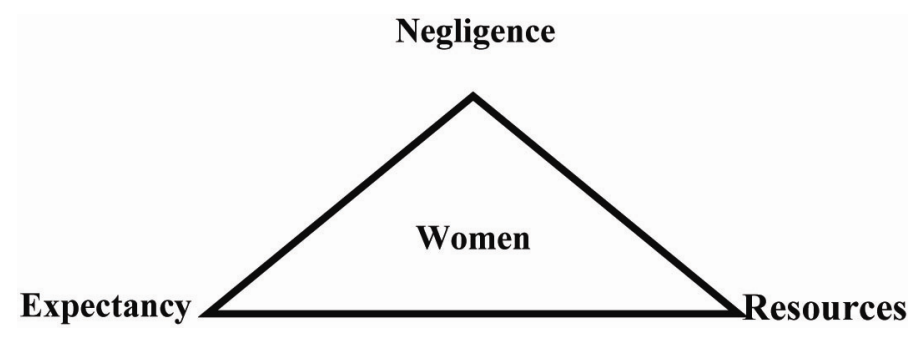

Figure 1. Triangular Attitude of Patriarchy

The figure 1 shows the three dimensions of Triangular Attitude of Patriarchy which functions through three angels one of them is Negligence, another one is Discriminatory Expectancy and third is Deprivation of Resources. This attitude creates several barriers and threads in women's career.

\subsection{Negligence}

Negligence is an important tort that covers a wide range of situations where persons negligently cause harm to women. Patriarchal performance or attitude harms female at large even female are not making any appeal and any arguments against this harmfulness. The various dimensions of the negligence in the patriarchal society are stated here.

\subsubsection{Negligence towards women}

The history signifies that the nature of the Indian society is always against to give the equal rights to women. Typical Indian male mentality doesn't permit to put the women on equal status as men, thus oppose or 'neglect' the judicial decisions. For instance, on $22^{\text {nd }}$ September 1951, is mentioned as a black day in Indian history because on which Jawaharlal Nehru (former Prime minister of India), released the Hindu Code bill. The bill has mentioned to remove all the constraints like Sati, child marriage, widow ostracization etc. which were imposed on Hindu women. But unfortunately the bill was not accepted. It was opposed by the Brahminical patriarchic society. Many Constitutional protective provisions have been made for women, which can be stated as in table 1 . 
Table 1. Protective Provisions for Women in Indian Constitutions

\begin{tabular}{|c|c|}
\hline Article & Brief description \\
\hline Article 14 & $\begin{array}{l}\text { Men and women have equal rights and opportunities in the political, economic, and } \\
\text { social spheres. }\end{array}$ \\
\hline Article $15(1)$ & $\begin{array}{l}\text { Prohibits discriminations against any citizen on the grounds of religion, race, caste, } \\
\text { sex, etc. }\end{array}$ \\
\hline Article $15(3)$ & $\begin{array}{l}\text { Special provision enabling the state to make affirmative discriminations in favour of } \\
\text { women. }\end{array}$ \\
\hline Article 16 & Equality of opportunities in matter of public appointments for all citizens. \\
\hline Article 39(a) & $\begin{array}{l}\text { State shall direct its policy towards securing all citizens' men and women equally, } \\
\text { the right to means of livelihood. }\end{array}$ \\
\hline Article $39(d)$ & Equal pay for equal work for both men and women \\
\hline Article 42 & $\begin{array}{l}\text { State to make provision for ensuring just and humane conditions of work and } \\
\text { maternity relief }\end{array}$ \\
\hline Article $51(\mathrm{~A})(\mathrm{e})$ & To renounce the practices derogatory to the dignity of women \\
\hline $\begin{array}{l}\text { Dowry Prohibition Act, } \\
1961\end{array}$ & $\begin{array}{l}\text { An amendment brought in } 1984 \text { to the dowry prohibition Act of } 1961 \text { made } \\
\text { women's subjection to cruelty a cognizable offence. }\end{array}$ \\
\hline Hindu Marriage Act 1955 & $\begin{array}{l}\text { Hindu marriage Act of } 1955 \text { amended in } 1976 \text { provides the right for girls to } \\
\text { repudiate a child marriage before attaining maturity. }\end{array}$ \\
\hline $\begin{array}{l}\text { Prohibition of Child } \\
\text { Marriage Act, } 2006\end{array}$ & $\begin{array}{l}\text { Child Marriage Restraint Act of } 1976 \text { raised the age for marriage of girls to } 18 \text { years } \\
\text { from } 15 \text { years and that of a boy to } 21 \text { years and made offences under this act } \\
\text { cognizable. }\end{array}$ \\
\hline $\begin{array}{l}\text { Hindu Succession } \\
\text { (Amendment) Act, } 2005\end{array}$ & (a) the daughter is allotted the same share as is allotted to a son \\
\hline Muslim Personal Law & This is an act to make provision for the application of the Muslim Personal law. \\
\hline $\begin{array}{l}\text { Protection from Domestic } \\
\text { Violence Act, } 2006\end{array}$ & $\begin{array}{l}\text { Domestic violence against women though pervasive is a largely invisible crime and } \\
\text { goes unrecognized, especially since domestic violence is considered as a family } \\
\text { matter. }\end{array}$ \\
\hline $\begin{array}{l}\text { Violence Against Women } \\
\text { Act of } 1994\end{array}$ & $\begin{array}{l}\text { The Violence Against Women Act of } 1994 \text { (1) enhanced investigations and } \\
\text { prosecutions of sex offenses. }\end{array}$ \\
\hline
\end{tabular}

As mentioned in table no. 1, drawing the strength from the constitutional commitments, the Government of India has been engaged in the continuous endeavor of concretely translating all the rights, commitments and safeguards incorporated in the Indian Constitution for women from de jure to de facto status (Shyam Kartik Mishra and Pradeep Kumar Pandey, 2012). Several Laws, Acts, Reports have been made concrete strategies for the women empowerment and for their socio-economic security. Even pervasive is a largely invisible crime and goes unrecognized, especially since domestic violence is considered as a family matter having an unspoken sanction in patriarchal society. As mentioned, Violence against Women Act was originally passed by Congress as part of the broader Violent Crime Control and Law Enforcement Act of 1994.

Data from the National Crime Victimization Survey (NCVS) indicate that the rate of intimate partner violence is approximately four times higher for females than males. There were 407,700 females that reported victimization by an intimate partner (3.1 per 1,000 persons aged 12 and older) in 2010, compared to 101,530 males (0.8 per 1,000 persons aged 12 and older) who reported victimization by an intimate partner. According to NCVS data, intimate partner victimization rates also vary by age and race. Females aged 18 or older generally experience higher rates of intimate partner violence than females aged 12 to 17. Rates of intimate partner violence have also been historically higher for black females than white females. At least 14 women per lakh population have faced atrocities like rape, molestation and sexual harassment in Maharashtra. Of the 24,206 rapes registered across the country in 2011, Maharashtra accounted for 1,701 cases or $7 \%$. And, of the 2.28 lakh crimes committed against women in India, 15,728 were in Maharashtra (6.87\%). The state ranks sixth in terms of percentage share. (Kulkarni, 2012). 


\subsection{Expectancy}

Expectancy theory proposes that an individual will decide to behave or act in a certain way because they are motivated to select a specific Behaviour over other Behaviours due to what they expect the result of that selected Behaviour will be (Oliver, 1974). According to Vroom (1964) laid the conceptual foundation for expectancy in work motivation theory. "Expectancy is defined as a momentary belief concerning the likelihood that a particular act will be followed by a particular outcome". The particular act is exerting effort in task performance, and the particular outcome is successful performance (Eden, 1998). Eden stated the expectancy in practical terms and mentioned, expectancy should be treated as a key to low-cost efforts to boost motivation. In this regard Ming-Te Wang and Jessica Degol mentioned that 'Achievement-related Behaviours such as educational and career choice are most directly related to expectations for success and the value attached to the various options perceived as available' (Ming-Te Wang and Jessica Degol, 2013). Sometimes woman behaves or acts like a puppet in hands of man. Because man feels that woman is not capable to live independently she is always dependent on men. This feeling grows due-to an expectation of our traditional view proposed by- Manusmriti. The origin of the Indian idea of appropriate female Behaviour can be traced to the rules laid down by Manu in 200 BC. He stated that,

"Pita rakshati kaumare, bharta rakshati youvane,

rakshanti sthavire putra, na stree swatantry amarhati”

(In childhood a female must be subject to her father, in youth to her husband, when her lord is dead to her sons; a woman must never be independent) (Manusmriti IX: 3) [Shastri, 2000].

Virginity and chastity are virtues, which are entrenched as part of the socialization pattern of girls. The expectation of bravery or "macho" Behaviour in men gets interpreted and accepted as the right to inflict violence on their part as opposed to acceptance of violence on the part of women who are expected to be not only chaste, but also obedient and "good". The typical image of a "good woman" is still one who upholds the honour of the family, maintains the "Culture of silence" prevailing in the private domain and is obedient and sacrificing. (Mathur, 2008).

\subsubsection{Expectations as Per Role of Women}

The expectations of households from women are charged as per role of women but everywhere in households have a patriarchic attitude which demands the different expectations with respect to role of women in the family. What patriarchic attitude demands discriminatory expectations from female as compared male. In this context Nandita Kapadia, Kundu and others has mentioned the finding regarding gender expectations on the basis of review of women studies. She stated that, Young married women are expected to seamlessly fit into several new gender roles as they enter their marital home. These concurrent and often competing roles include those of daughter -in-law, wife, and mother. The related gender role expectations are divided into four domains- household chores, mobility, so-called modesty behaviours, and sex (Nandita Kapadia-Kundu, Manisha Khale, Sachin Upadhaye, Deepti Chavan, 2007). Woman plays minimum four types of role in her life. As per the role what patriarchic expectations are expected from them, those are explained in this section.

\subsubsection{Role as a Daughter}

Several observations of discriminatory expectancy between daughter and son are found in regular practices of patriarchic society. In the Indian society girls are marginalized in almost every sphere of life due to its denial of equal status to them. The patriarchal system of the society forces to the women to be confined to the four walls of their homes largely engaged in the household chores. There are various hindrances to the identity of women (report, 2010-2011) the girl is discriminated in terms of taking education, also enjoying jobs. The head of the family doesn't expect earnings from females. The family just expects that girls have to take care of children at home and do the unpaid work for the family. She has also to work in own farm or work as a daily wages in others' farm.

\subsubsection{Role as a Wife}

Nandita Kapadia-Kundu and others has studied the gender roles and expectations. This study found that the husbands' expectations were in two primary domains- modesty behaviours and sex. The range of modesty behaviours reported included not talking or laughing loudly, respecting elders, not talking with other men, wearing a sari and tying one's hair back (not leaving it loose). Husbands also expected their new brides to fulfill their sexual needs and desires (Nandita Kapadia-Kundu, Manisha Khale, Sachin Upadhaye, Deepti Chavan, 2007).

\subsubsection{Role as a Daughter-in-law}

The expectations from daughter-in-law are primarily related to household chores and Behaviour with family elders and unknown males. The research study found that, ... the daughter-in-law should adhere to fulfill those expectations 
so that they met family standards, but if the family perceived that she failed to do so, then these households often supported the daughter in- law by mentoring her and teaching her the ways of their family so that she could fit in better at the marital home (Nandita Kapadia-Kundu, Manisha Khale, Sachin Upadhaye, Deepti Chavan, 2007).

\subsubsection{Role as a Mother}

Women studies found that Some of the gender role expectations of motherhood, evident from the data included having a child soon after marriage and having a male child. About 83 per cent of the 61 young women interviewed conceived before one year of marriage. Of these half conceived within the first six months. This could be due to two reasons- first, the overarching norms that young married women must prove their fertility, and second, their initiation into a regular sexual life without the use of contraceptives. ...Households had particularly strong expectations of early childbearing in fact, failure to do so could precipitate violence (Nandita Kapadia-Kundu, Manisha Khale, Sachin Upadhaye, Deepti Chavan, 2007).

\subsection{Resources}

The third aspect of triangular attitude of patriarchy is 'Resources'. In present study resource theories were operated and developed to construct as measures. Women play a pivotal role in the overall progress of a country as they constitute half the human resources of a nation. The economic wealth of a country is seriously depleted if about half of the nation's human resource is neglected (India, 2010). The different types of resource theories like gendered resource theory, relative resource theory etc. has described the effect of resources either less or more and the related impact on men and women. These resources sometimes become the reasons for the wife abuse. Breadwinning related to wife sometimes becomes dangerous and reasons for her abuse in the family. Two social structural perspectives commonly used to explain wife abuse are resource theory and alternative resource theory. These theories suggest that level of resources is the primary predictor of wife abuse. Specifically, they argue that married men who have few resources to offer (resource theory), or fewer resources than wives (relative resource theory), are more likely than their resource-rich counterparts to use violence. (Lang, et al., 2005) Violence serves as a compensation for their shortage of resources. These theories have received support in the plethora of studies (Anderson, 1997); (Hotaling.G.T., 1986); (McCloskey, 1996). These structural explanations ignore cultural variables, however, and take for granted that married men want to be breadwinners, particularly in comparison to their wives. In other words, rather than accurately reflecting the variability in men's gender ideologies, such arguments assume all men to be traditional. (Lang, et al., 2005).

'Resource theory' is an approach. According to this theory, power is generally associated with resources brought into a marriage by each spouse. Consequently, the greater the resources either spouse has in comparison to the other; the greater will be his or her marital power. These resources are usually economic in nature, namely education, occupational status, and income. Giving the gender-based stratification in most societies, these resources are unequally distributed between men and women (Ramu, 2003) Girls are not permanent member of the home. Woman goes away to other family after marriage. Parents didn't want to give land, house, and other resources to her in-laws. Parent does spend lot money on her marriage. Distribution of resources and crisis in property right is in built of marriage institutions. At least parent should focus on girl's education as a resource. She has to be independent and efficient to do trained professions and capable to learn lifetime.

On this theoretical background, TAP is a conceptualized construct of this research in which three different theories like Expectancy, Resource and Negligence are operated to construct TAP.

\section{Related Literature Review}

"Gender" refers to the roles, responsibilities, attitudes and power relations that are socially constructed by and assigned to men and women of a given society or community. These constructs vary greatly by culture, geographic region, socioeconomic status and context and they change over time. (C.Lathamma, 2012). Several studies found the gender biased practices in the society. Nobel Laureate Amartya Sen' draws the gender inequality in his essay entitled Many Faces of Gender Inequality. He states that gender inequality exists in most parts of the world, from Japan to Morocco, from Uzbekistan to the United States of America. However, inequality between women and men can take vary many different forms. (Sen, 2001). According to Srivastava Achala\& Singh, A.K, the reality of women's socio-economic condition has put them in the most disadvantaged \& deprived communities of the world. In India gender relations are influenced by traditional hierarchies based on Patriarchy, caste \& ethnicity and compounded by inequalities of wealth $\&$ power. They depicted the socioeconomic status of women in their thesis entitled Socio-Economic Status of Women and Gender Disparity: An Inter-District Study of Uttar Pradesh, 2004. This study found that, women's own attitudes to education \& employment also need to be changed. The change in attitudes can be brought about through well-planned 
education \& communication activities. (Srivastava, 2004). In the Indian context, Eapen M., Mehta A. focused on a gendered analysis of the Approach in the paper entitled Gendering the Twelfth Plan: A Feminist Prospective. The central theme of the paper was that if the goal of the system is inclusion, than the generation of livelihoods and employment should be the driving force for the growth and development of feminist perspective. (Eapen M., 2010)

\section{Objectives}

Objectives are the road map of the research frame. Following objectives were stated in this research-

1. To study the Triangular Attitude of Patriarchy towards women.

2. To study the impact of TAP on socio-economic status of rural-urban women.

3. To study the gender issues in Lifelong Learning of women.

\section{Hypothesis}

1. $\mathrm{H}_{1}$ : There is a significant difference between urban \& rural gender issues in terms of triangular attitude of patriarchy.

2. $\mathrm{H}_{1:}$ There is a significant difference between the issues TAP towards housewives, members of SHGs and women entrepreneurs.

\section{Limitations}

This study has three limitations that warrant further descriptions. One limitation is that survey researches such as which one are not intended to promote broad generalizations to other contexts. Second limitation was that, the selection of respondents was aimed at identifying factors that explore the issues of socio-economic, gender inequality and assess the needs of different groups of women who are members of SHGs, Entrepreneurs (Small Scale Business) and Housewives other than the service sector. In service women were not selected in the sample. This is not census study but it is the sample study. The only women's responses and opinions about the issues were collected through the sample cases and male respondents have not opportunity to give explanations about their side in this research. Only Pune district was selected as a sample for the study. This is a geographical limitation of this study. In this study only TAP as a gender issue has been taken into consideration other than issues in quality of women's lifelong learning, issues in lifelong learning system in India.

\section{Method}

The purpose of this study was understood issues of women's LLL. For this purpose the survey research paradigm has been adopted. Housewives, members of SHG and women entrepreneurs were consisted as the population in the present study. Since the population was not easily identifiable, the researcher used snow-ball sampling method to identify and select sample. An effort was also made to ensure representation of different segments of women lifelong learners. To ensure this representation researcher selected Housewives, Member of SHG and Entrepreneurs through snow-ball sampling. Entrepreneurs were selected in this study those who run a small scale business and their annual income approximately not more than 100000/- rupees. For present research the snowball sampling has been employed to establish the chain or link to reach the right respondents. The random sampling was used for selecting the women of each type like housewives, women entrepreneurs and women member of self-help groups. Women were selected as equal sample from each category of women as 100 housewives, 100 members of the SHGs and 100 entrepreneurs from urban and rural area respectively. Total 600 women were selected as sample. The equal weightage has been given to rural and urban area while sampling.

The concern of researcher was to find the gaps between rural and urban with special reference to TAP towards Housewives, Members of the SHGs and Women Entrepreneurs. TAP Construct was measured by likert scale in this research. There are three angles of patriarchic attitudes i.e. Negligence, Expectancy and Resources. Each angle was measured through the six statements which are organized with five points such as Strongly Disagree, Disagree, Undecided, Agree, and Strongly Agree. The data was collected from rural and urban area of Pune District. The respondents were Housewives and Members of the SHGs and Women Entrepreneurs. For this purpose researcher formulated the hypothesis and tested them by Mann Whitney Test and The Kruskal-Wallis test.

\section{Findings and Discussions}

\subsection{Ranks of Patriarchic Negligence towards Women}

The different aspect of the negligence towards women has occurred as the barriers on their ways of development and lifelong Learning. It breaks the considerations of laws and moral ethics in the society. To determine the ranking of the different Triangular Attitude of Patriarchy as a socio-economic and gender issues, the "Relative Importance Index" 
(RII) was adopted. This method transforms the five-point Likert scale to help determine the ranking of each factor, using the following expression

$$
\mathrm{RII}=\frac{\sum_{i=1}^{5} \text { aixi }}{5 * N}
$$

Where ai is a constant expressing the weight of the ith response; xi is the frequency of the ith response of the total responses for each cause; $i$ is the response category index, where $\mathrm{i}=1,2,3,4$ and 5 , respectively, $\mathrm{N}$ is the total number of respondents . (Adnan Enshassi, Peter E. Mayer, Shrif Mohamed and Fayez EL-Masri, 2007).

Table 2. Relative Importance index and ranks of Patriarchic Negligence

\begin{tabular}{lcccccccc}
\hline & 1 & 2 & 3 & 4 & 5 & & & \\
\hline & $\begin{array}{l}\text { Strongly } \\
\text { Disagree }\end{array}$ & Disagree & Undecided & Agree & $\begin{array}{c}\text { Strongly } \\
\text { Agree }\end{array}$ & aixi & RII & Rank \\
$\begin{array}{l}\text { Equal Rights and Opportunities } \\
\text { for Men and Women }\end{array}$ & 138 & 148 & 12 & 259 & 43 & 1721 & 0.57 & 5 \\
$\begin{array}{l}\text { Equal pay for Equal Work for } \\
\text { Men and Women }\end{array}$ & 179 & 206 & 32 & 150 & 33 & 1452 & 0.48 & 6 \\
$\begin{array}{l}\text { Men do not bother to support } \\
\text { women's lifetime education }\end{array}$ & 64 & 181 & 32 & 135 & 188 & 2002 & 0.67 & 4 \\
$\begin{array}{l}\text { Men is negligence towards the } \\
\text { unpaid work at home }\end{array}$ & 51 & 152 & 26 & 136 & 235 & 2152 & 0.72 & 2 \\
$\begin{array}{l}\text { Restriction to girl in selecting } \\
\text { life partner }\end{array}$ & 52 & 172 & 25 & 173 & 178 & 2053 & 0.68 & 3 \\
$\begin{array}{l}\text { Women hides violence and } \\
\text { casual attitude of Society }\end{array}$ & 17 & 83 & 39 & 198 & 263 & 2407 & 0.80 & 1 \\
\hline
\end{tabular}

Table 2 shows that, 'Women hide the physical and sexual harassment due to 'violence supportive attitude' of the society was ranked first by respondents, with $(\mathrm{RII}=0.80)$. This result indicates that the level of agreement to this statement was the highest prioritized of negligence. Women hides the physical and sexual harassment because 'violence supportive attitude of the society'. Sexual purity of women is highly sensitive and prestigious matter in Indian male dominated family. Women hide physical and sexual violence due-to the patriarchic pressure and casual attitude of society. According to respondents, violence supportive attitude is highly determinant factors of the negligence towards women.

'Men do not consider the unpaid-work and even no importance is given to unpaid work (cooking, cleaning etc.) at home. It was ranked second, with (RII=0.72). Such opinions of the respondents are taking into consideration in real problem of housekeeping unpaid work. It is faced by the all categories of the women. Men never consider the unpaid work of home is as an important task for them. They never take interest in such a work so it is neglected by them.

'Girl has not got any freedom for the selection of her life partner; in this regard her ambitions and willingness are neglected.' This statement was ranked third, with $(\mathrm{RII}=0.68)$. In family girls are neglected in decision making even to select her life partner. It is injustice to her. Women's opinions are not taken into consideration in decision making process because no any resources are made belong to them.

'Man fears that, highly educated wife is not easy to handled therefore they don't bother to support her lifetime learning.' It was ranked fourth with $(\mathrm{RII}=0.67)$. This result indicates that the importance of girls' education is realized even in mail dominated society. In present phenomena, men required their life partner should be qualified and educated for doing job and getting financial support to family.

'We women are enjoying equal rights and opportunities in the political, economic and social spheres like men' was ranked fifth, with $(\mathrm{RII}=0.57)$. This result indicates that maximum women agreed with this statement. It seems that women are gradually coming forward in socio-political practices.

'We women are getting equal pay for equal work like men' was ranked sixth, with $(\mathrm{RII}=0.48)$. This result indicates that maximum women had disagreed to this statement. They felt that they were not treated as equal to male in taskforce with respect to equal payment. This sexual discrimination in workforce is serious issues till now in India. Women are getting equal pay for equal work like men is highly and mostly disagreed by women. 


\subsection{Patriarchic Discriminatory Expectancy}

Table 3 shows the Relative Importance Indices and the ranks of each statement of discriminatory expectancy that are perceived to cause hindrance to improvement in women's behavior for quality performance.

Table 3. Relative importance index and ranks of Patriarchic Discriminatory Expectancy

\begin{tabular}{|c|c|c|c|c|c|c|c|c|}
\hline & 1 & 2 & 3 & 4 & 5 & & & \\
\hline Statements & $\begin{array}{l}\text { Strongly } \\
\text { Disagree }\end{array}$ & Disagree & Undecided & Agree & $\begin{array}{l}\text { Strongly } \\
\text { Agree }\end{array}$ & aixi & RII & Rank \\
\hline $\begin{array}{l}\text { Fear of Desertion \& } \\
\text { fulfillment of demands }\end{array}$ & 39 & 121 & 42 & 214 & 184 & 2183 & 0.73 & 4 \\
\hline $\begin{array}{l}\text { Men's Expectation as a "Good } \\
\text { Woman" }\end{array}$ & 16 & 47 & 21 & 113 & 403 & 2640 & 0.88 & 1 \\
\hline $\begin{array}{l}\text { Inter-caste marriage of girl } \\
\text { creates violence in the Family }\end{array}$ & 37 & 56 & 21 & 126 & 360 & 2516 & 0.84 & 2 \\
\hline $\begin{array}{l}\text { Parent's expectation about } \\
\text { girl's earnings and their } \\
\text { professional career. }\end{array}$ & 49 & 146 & 43 & 240 & 122 & 2040 & 0.68 & 5 \\
\hline $\begin{array}{l}\text { Women's status in family \& } \\
\text { issue of dowry }\end{array}$ & 89 & 207 & 33 & 131 & 140 & 1826 & 0.61 & 6 \\
\hline $\begin{array}{l}\text { women cannot do the business / } \\
\text { service freely due to the high } \\
\text { expectations }\end{array}$ & 20 & 58 & 20 & 199 & 303 & 2507 & 0.83 & 3 \\
\hline
\end{tabular}

This group of discriminatory expectancy factors mentioned in table 3 was ranked by the survey respondents. This study found that the two highly ranked factors of discriminatory expectancy were: 1) "Men expects as a "Good woman" is still now upholds the honor of the family and maintained the "Culture of Silence" prevailing in the private domain and is obedient and sacrificing'. This statement was ranked first with ( $\mathrm{RII}=0.88)$. It was the highest degree of agreement with this statement. Such a patriarchy expects slavery among women. Another factor is 2) 'whether girl makes inter-caste marriage which creates violence in the family'. It was second ranked with (RII $=0.84$ ). Such a factor could be related to patriarchic mentality which creates the discriminatory expectancy between male and female. Caste system is pressurized by patriarchic power which does not allow women to make inter-caste marriage. It expects that girl has to marry within the caste otherwise face to violence.

'As compared to men, women cannot able to do the business freely due to the high patriarchic expectations about family responsibility was ranked third, with $(\mathrm{RII}=0.83)$. This result indicates that women felt they could not do the job frankly and freely because of over burden of the family responsibility and housekeeping work. 'Woman tries to fulfill the demands of family though she is abused by men because of only fear of desertion is so high among women' was ranked fourth with $(\mathrm{RII}=0.73)$. This result indicates that fear of desertion was taken into consideration as the fourth rank cause of creating slavery mentality among women. Such a patriarchic expectancy creates fear among women and breaks the freedom of them. Many of them faced with disparity. This discriminatory expectancy of patriarchy was an important and determinant factor in the gender inequality. Whether parent doesn't expect girl's earnings that effects on her professional career was ranked fifth with $(\mathrm{RII}=0.68)$. It indicates that the expectancy of family about girl's earning is increased day by day. Whether brings good dowry woman gets good status and importance in the family, otherwise she may face the domestic violence was ranked sixth with $(\mathrm{RII}=0.61)$ this results indicates that the issue of dowry is gone into black out. Now it is not a focus-point of social discussions.

\subsection{Patriarchic Attitude towards Resources}

Power is generally associated with resources. Resources profoundly affects individuals' lives and hence its access to education, reduces domestic violence, increases mobility, helps in decision making, increases status of women, decrease in excess fertility, improves child health. But maximum resources are under the controlled of male. Women had been become the puppet in hands of men because they are deprived from access the sources. In this regard the data was collected by Likert Scale which is presented in table 4 . 
Table 4. Relative importance index and ranks of Patriarchic Attitude towards Resources

\begin{tabular}{|c|c|c|c|c|c|c|c|c|}
\hline & 1 & 2 & 3 & 4 & 5 & & & \\
\hline Statements & $\begin{array}{l}\text { Strongly } \\
\text { Disagree }\end{array}$ & Disagree & Undecided & Agree & $\begin{array}{l}\text { Strongly } \\
\text { Agree }\end{array}$ & aixi & RII & Rank \\
\hline $\begin{array}{l}\text { Women's demand for resources } \\
\& \text { household issues }\end{array}$ & 60 & 175 & 55 & 182 & 128 & 1938 & 0.646 & 5 \\
\hline $\begin{array}{l}\text { Women's knowledge about their } \\
\text { work }\end{array}$ & 4 & 12 & 15 & 131 & 438 & 2787 & 0.93 & 2 \\
\hline $\begin{array}{l}\text { Women's in-house training } \\
\text { increases productivity }\end{array}$ & 4 & 11 & 15 & 122 & 448 & 2799 & 0.934 & 1 \\
\hline $\begin{array}{l}\text { Daughter's share in parent's } \\
\text { property }\end{array}$ & 103 & 110 & 35 & 284 & 68 & 1904 & 0.634 & 6 \\
\hline $\begin{array}{l}\text { If daughter asking share in } \\
\text { Parent's property that creates } \\
\text { issues. }\end{array}$ & 45 & 126 & 58 & 182 & 189 & 2144 & 0.714 & 4 \\
\hline $\begin{array}{l}\text { Women's power in } \\
\text { decision-making and own } \\
\text { property rights. }\end{array}$ & 34 & 34 & 23 & 128 & 381 & 2588 & 0.862 & 3 \\
\hline
\end{tabular}

Whether the women receive regular in-house training regarding their fields of work effects on productivity was ranked first with ( $\mathrm{RII}=0.934)$. This statement was accepted at the highest degree of agreement by the women. It shows the intensity of needs of in house training at work place. Women have highly curiosity to improve the quality performance in practices. Local training agencies have to organize the in house training at the nearest campus for women. Women demands training to improve the practices which was found most needful resource to them.

Whether the women know what kind of knowledge and skills they needed regarding their fields of work; that affects productivity was ranked second with $(\mathrm{RII}=0.93)$. This result indicates that women have realized the importance of knowledge and skills to improve their quality performance.

Women are powerless in decision making due to lack of resource was ranked three with ( $\mathrm{RII}=0.862)$. Women have understood the proper use of resources. They want use the resources to improve their career. Mostly women demand the training and education as a resource and they want to improve their personal and family wellbeing.

Whether the women ask for her proportions of the parent's property after marriage that creates the disturbance and violence which may be result in the restriction to go to her father's house in future was ranked fourth with (RII $=0.714$ ) The share in property of parents is allotted to the daughter as the same allotted to a son was ranked sixth with $(\mathrm{RII}=0.634)$. Property right till now are not a prioritized by women due to the heartily respect with parents.

\subsection{Comparison between Rural and Urban effect of TAP}

This study formulated the hypothesis on Triangular Attitude of Patriarchy as a gender issues which is mentioned as follow-

Ho: There is no difference between urban \& rural gender issues in terms of triangular attitude of patriarchy.

H1: There is a difference between urban \& rural gender issues in terms of triangular attitude of patriarchy.

The hypothesis is tested by the Mann Whitney $\mathrm{U}$ test. The data is presented in the table 5 . 
Table 5. Mann Whitney U test for Rural Urban-wise Function of TAP Towards women

\begin{tabular}{|c|c|c|c|c|c|c|c|c|c|c|c|c|}
\hline \multirow{3}{*}{ Social-Economic and Gender issues } & \multicolumn{6}{|c|}{ Rural } & \multicolumn{6}{|c|}{ Urban } \\
\hline & 1 & 2 & 3 & 4 & 5 & & 1 & 2 & 3 & 4 & 5 & \\
\hline & \multirow{2}{*}{$\begin{array}{l}\text { Strongly } \\
\text { Disagree }\end{array}$} & \multirow[t]{2}{*}{ Disagree } & \multirow[t]{2}{*}{ Undecided } & \multirow[t]{2}{*}{ Agree } & \multirow{2}{*}{$\begin{array}{c}\text { Strongly } \\
\text { Agree }\end{array}$} & \multirow[t]{2}{*}{ RII } & \multirow{2}{*}{$\begin{array}{l}\text { Strongly } \\
\text { Disagree }\end{array}$} & \multirow[t]{2}{*}{ Disagree } & \multirow[t]{2}{*}{ Undecided } & \multirow[t]{2}{*}{ Agree } & \multirow{2}{*}{$\begin{array}{l}\text { Strongly } \\
\text { Agree }\end{array}$} & \multirow[t]{2}{*}{ RII } \\
\hline Negligence / Expectancy/Resources Statements & & & & & & & & & & & & \\
\hline Equal rights and opportunities for men and women & 74 & 67 & 5 & 128 & 26 & 0.48 & 64 & 81 & 7 & 131 & 17 & 0.488 \\
\hline Equal pay for equal work for men and women & 98 & 96 & 10 & 79 & 17 & 0.576 & 81 & 110 & 22 & 71 & 16 & 0.57 \\
\hline $\begin{array}{l}\text { Men do not bother to support women's lifetime } \\
\text { education }\end{array}$ & 28 & 103 & 13 & 61 & 95 & 0.576 & 36 & 78 & 19 & 74 & 93 & 0.618 \\
\hline Men neglected towards the unpaid work at home & 23 & 80 & 11 & 59 & 127 & 0.652 & 28 & 72 & 15 & 77 & 108 & 0.638 \\
\hline Restriction to in selecting her life partner & 25 & 93 & 12 & 74 & 96 & 0.656 & 27 & 79 & 13 & 99 & 82 & 0.64 \\
\hline Women hide violence and casual attitude of society. & 7 & 53 & 14 & 88 & 138 & 0.662 & 10 & 30 & 25 & 110 & 125 & 0.668 \\
\hline Fear of desertion \& fulfillment of demands & 17 & 64 & 14 & 104 & 101 & 0.682 & 22 & 57 & 28 & 110 & 83 & 0.674 \\
\hline Men's expectation from woman as a "Good Women" & 10 & 25 & 8 & 47 & 210 & 0.692 & 6 & 22 & 13 & 66 & 193 & 0.684 \\
\hline $\begin{array}{l}\text { Inter-caste marriage of girl creates violence in the } \\
\text { family }\end{array}$ & 16 & 26 & 11 & 58 & 189 & 0.724 & 21 & 30 & 10 & 68 & 171 & 0.686 \\
\hline $\begin{array}{l}\text { Parent's expectation of earning of girl effects on her } \\
\text { professional carrier. }\end{array}$ & 25 & 73 & 16 & 111 & 75 & 0.738 & 24 & 73 & 27 & 129 & 47 & 0.71 \\
\hline Women's Status in family $\&$ issue of dowry & 53 & 117 & 11 & 46 & 73 & 0.746 & 36 & 90 & 22 & 85 & 67 & 0.716 \\
\hline $\begin{array}{l}\text { Women's responsibilities towards home } \& \text { negligence } \\
\text { of outside paid work }\end{array}$ & 8 & 32 & 8 & 92 & 160 & 0.798 & 12 & 26 & 12 & 107 & 143 & 0.806 \\
\hline Women's demand for resources \& household issues & 26 & 92 & 22 & 92 & 68 & 0.842 & 34 & 83 & 33 & 90 & 60 & 0.826 \\
\hline Women's knowledge about their work & 2 & 7 & 6 & 64 & 221 & 0.852 & 2 & 5 & 9 & 67 & 217 & 0.828 \\
\hline Women's in-house training increase productivity & 2 & 2 & 5 & 59 & 232 & 0.862 & 2 & 9 & 10 & 63 & 216 & 0.864 \\
\hline Daughter's share in Parental Property & 45 & 50 & 22 & 149 & 34 & 0.882 & 58 & 60 & 13 & 135 & 34 & 0.878 \\
\hline $\begin{array}{l}\text { If daughter asking share in parent's property creates } \\
\text { issues }\end{array}$ & 15 & 60 & 27 & 87 & 111 & 0.93 & 30 & 66 & 31 & 95 & 78 & 0.922 \\
\hline $\begin{array}{l}\text { Women's power in decision-making and own property } \\
\text { rights. }\end{array}$ & 21 & 19 & 9 & 48 & 203 & 0.946 & 13 & 15 & 14 & 80 & 178 & 0.928 \\
\hline
\end{tabular}

Rank all scores together, ignoring which group they belong to, table 6.

Table 6. RII \& Rank

\begin{tabular}{|c|c|c|c|c|c|c|c|c|}
\hline Area & $\mathrm{RII}^{@}$ & Rank & Area & RII & Rank & Area & RII & Rank \\
\hline $\mathrm{R}$ & 0.480 & 1 & $\bar{U}$ & 0.674 & 13 & $\bar{U}$ & 0.826 & 25 \\
\hline $\mathrm{U}$ & 0.49 & 2 & $\mathrm{R}$ & 0.682 & 14 & $\mathrm{U}$ & 0.828 & 26 \\
\hline $\mathrm{U}$ & 0.57 & 3 & $\mathrm{U}$ & 0.684 & 15 & $\mathrm{R}$ & 0.842 & 27 \\
\hline $\mathrm{R}$ & 0.576 & 4 & $\bar{U}$ & 0.686 & 16 & $\mathrm{R}$ & 0.852 & 28 \\
\hline $\mathrm{R}$ & 0.58 & 5 & $\mathrm{R}$ & 0.692 & 17 & $\mathrm{R}$ & 0.862 & 29 \\
\hline $\mathrm{U}$ & 0.618 & 6 & $\mathrm{U}$ & 0.71 & 18 & $\mathrm{U}$ & 0.864 & 30 \\
\hline $\bar{U}$ & 0.638 & 7 & $\bar{U}$ & 0.716 & 19 & $\bar{U}$ & 0.878 & 31 \\
\hline $\bar{U}$ & 0.64 & 8 & $\mathrm{R}$ & 0.724 & 20 & $\mathrm{R}$ & 0.882 & 32 \\
\hline $\mathrm{R}$ & 0.652 & 9 & $\mathrm{R}$ & 0.738 & 21 & $\bar{U}$ & 0.922 & 33 \\
\hline $\mathrm{R}$ & 0.656 & 10 & $\mathrm{R}$ & 0.746 & 22 & $\mathrm{U}$ & 0.928 & 34 \\
\hline $\mathrm{R}$ & 0.662 & 11 & $\mathrm{R}$ & 0.798 & 23 & $\mathrm{R}$ & 0.93 & 35 \\
\hline $\mathrm{U}$ & 0.668 & 12 & $\bar{U}$ & 0.806 & 24 & $\mathrm{R}$ & 0.944 & 36 \\
\hline
\end{tabular}

(a) RII= Relative Importance Index; U=Urban; R=Rural

Add up the ranks for Rural Area, to get $T_{R}$ 


$$
\mathrm{T}_{\mathrm{R}}=1+4+5+9+10+11+14+17+20+21+22+23+27+28+29+32+35+36=344
$$

Add up the ranks for urban area, to get $\mathrm{T} 2$

$$
\mathrm{T}_{\mathrm{U}}==2+3+6+7+8+12+13+15+16+18+19+24+25+26+30+31+33+34=322
$$

Select the larger rank. In this case it's $\mathrm{T}_{1}$

Number of observations in each group, and the number of observations in the group that gave the larger rank total.

$$
\begin{gathered}
\text { Therefore } \mathrm{n} 1=18 ; \\
\mathrm{n} 2=18 ; \\
\mathrm{nx}=18
\end{gathered}
$$

Find $\mathrm{U}$ ie test statistics (Note: $\mathrm{Tx}$ is the larger rank total $=344$ )

$$
\mathrm{U}=\mathrm{n} 1 . \mathrm{n} 2+-\mathrm{Tx} ; \mathrm{U}=495-344=151
$$

Use a table of critical $U$ values for the Mann-Whitney U Test at 1\% 1.o.s level of significance

$$
\mathrm{U}_{0.01}=81
$$

Decision Rule: Reject $\mathrm{H}_{0}$ if $\mathrm{U}_{\text {cal }}$ is less than or equal to $\mathrm{U}_{\text {table }}$ otherwise we accept $\mathrm{H}_{0}$.

$$
\text { Here } \mathrm{U}_{\text {cal }}=151 \& \mathrm{U}_{\text {table }}=81 \text {, We accept } \mathrm{H}_{0} \text { at } 1 \% \text { 1.o.s }
$$

There is no significant difference between urban-rural gender issues in terms of triangular attitude of patriarchy. It means that a triangular attitude of patriarchy is equally problematic to urban women as rural. Urban women are neglected, deprived from resources and they are faced discriminatory expectancy of patriarchy as equally rural women. Triangular Attitude of Patriarchy towards women was found influenced in urban as equal in rural area even educational rate, women employment rate, industrial development rate, number of in service women is in high ratio of urban area rather than rural. Gender equality is a value which could not be inculcated only through education or socioeconomic status but it is depend on vision of person. Only social treatment can give the solutions for change such views because it is a collective responsibility of the society. 


\subsection{Group wise Effects of TAP}

Table 7. The Kruskal-Wallis test of TAP among Housewives, SHGs and Women Entrepreneurs:

\begin{tabular}{|c|c|c|c|c|c|c|c|c|c|c|c|c|c|c|c|c|c|c|}
\hline $\begin{array}{l}\text { Social-Economic and } \\
\text { Gender issues }\end{array}$ & & & Ho & ewi & & & & & & IGs & & & & & men & atrepr & eneurs & \\
\hline SD: Strongly Disagree, & 1 & 2 & 3 & 4 & 5 & & 1 & 2 & 3 & 4 & 5 & & 1 & 2 & 3 & 4 & 5 & \\
\hline $\begin{array}{c}\text { Undecided, A:Agree, } \\
\text { SA: Strongly Agree } \\
\text { Negligence / } \\
\text { Expectancy/Resources } \\
\text { Statements } \\
\end{array}$ & SD & $\mathrm{D}$ & UD & A & SA & RII & $\mathrm{SD}$ & $\mathrm{D}$ & UD & A & SA & RII & SD & $\mathrm{D}$ & UD & A & SA & RII \\
\hline $\begin{array}{l}\text { Equal rights and } \\
\text { opportunities for Men } \\
\text { and Women }\end{array}$ & 39 & 48 & 4 & 97 & 12 & 0.596 & 52 & 49 & 2 & 82 & 15 & 0.56 & 47 & 51 & 6 & 80 & 16 & 0.568 \\
\hline $\begin{array}{l}\text { Equal pay for equal } \\
\text { work for men and } \\
\text { women }\end{array}$ & 63 & 68 & 6 & 54 & 9 & 0.478 & 69 & 71 & 10 & 37 & 13 & 0.454 & 47 & 67 & 16 & 59 & 11 & 0.52 \\
\hline $\begin{array}{l}\text { Men do not bother to } \\
\text { support women's } \\
\text { lifetime education }\end{array}$ & 26 & 60 & 10 & 44 & 60 & 0.652 & 19 & 63 & 14 & 39 & 65 & 0.668 & 19 & 58 & 8 & 52 & 63 & 0.682 \\
\hline $\begin{array}{l}\text { Men negligence towards } \\
\text { the unpaid work at home }\end{array}$ & 11 & 54 & 8 & 42 & 85 & 0.736 & 14 & 53 & 9 & 45 & 79 & 0.722 & 26 & 45 & 9 & 49 & 71 & 0.694 \\
\hline $\begin{array}{l}\text { Restriction to girl in } \\
\text { selecting her life partner }\end{array}$ & 13 & 60 & 8 & 64 & 55 & 0.688 & 22 & 69 & 7 & 42 & 60 & 0.65 & 17 & 43 & 10 & 67 & 63 & 0.716 \\
\hline $\begin{array}{l}\text { A woman hides violence } \\
\text { and casual attitude of } \\
\text { society. }\end{array}$ & 6 & 31 & 9 & 64 & 90 & 0.802 & 7 & 34 & 13 & 58 & 88 & 0.786 & 4 & 18 & 17 & 76 & 85 & 0.82 \\
\hline $\begin{array}{l}\text { Fear of desertion \& } \\
\text { fulfillments of demands }\end{array}$ & 10 & 44 & 15 & 63 & 68 & 0.736 & 14 & 42 & 14 & 68 & 62 & 0.722 & 15 & 35 & 13 & 83 & 54 & 0.726 \\
\hline $\begin{array}{l}\text { Men's expectation from } \\
\text { woman as a "Good } \\
\text { Women". }\end{array}$ & 6 & 17 & 3 & 31 & 143 & 0.888 & 3 & 14 & 11 & 39 & 133 & 0.886 & 7 & 16 & 7 & 43 & 127 & 0.868 \\
\hline $\begin{array}{l}\text { Inter-caste marriage of } \\
\text { girl creates violence in } \\
\text { the family }\end{array}$ & 14 & 16 & 3 & 40 & 127 & 0.85 & 7 & 17 & 9 & 44 & 123 & 0.86 & 16 & 23 & 9 & 42 & 110 & 0.808 \\
\hline $\begin{array}{l}\text { Parent's expectation of } \\
\text { earning effects to } 1 \\
\text { carrier of girl. }\end{array}$ & 17 & 46 & 16 & 83 & 38 & 0.68 & 20 & 58 & 14 & 74 & 34 & 0.644 & 12 & 42 & 13 & 83 & 50 & 0.718 \\
\hline $\begin{array}{l}\text { Women's status in } \\
\text { family \& issue of } \\
\text { dowry. }\end{array}$ & 25 & 74 & 8 & 45 & 48 & 0.618 & 33 & 72 & 9 & 42 & 44 & 0.592 & 31 & 61 & 16 & 44 & 48 & 0.618 \\
\hline $\begin{array}{l}\text { Women's } \\
\text { responsibilities towards } \\
\text { home \& negligence of } \\
\text { outside paid work }\end{array}$ & 5 & 21 & 6 & 60 & 108 & 0.846 & 5 & 21 & 6 & 60 & 108 & 0.846 & 6 & 20 & 9 & 73 & 92 & 0.826 \\
\hline $\begin{array}{l}\text { Women's demand for } \\
\text { resources \& household } \\
\text { issues }\end{array}$ & 19 & 60 & 16 & 57 & 48 & 0.656 & 18 & 61 & 20 & 63 & 38 & 0.642 & 23 & 54 & 19 & 62 & 42 & 0.646 \\
\hline $\begin{array}{l}\text { Women's knowledge } \\
\text { about their work }\end{array}$ & 2 & 8 & 5 & 44 & 141 & 0.914 & 1 & 3 & 5 & 34 & 156 & 0.938 & 1 & 1 & 5 & 53 & 140 & 0.93 \\
\hline $\begin{array}{l}\text { Women's in-house } \\
\text { training increases } \\
\text { productivity }\end{array}$ & 0 & 4 & 4 & 40 & 152 & 0.94 & 2 & 4 & 5 & 33 & 156 & 0.938 & 2 & 3 & 6 & 49 & 140 & 0.922 \\
\hline $\begin{array}{l}\text { Daughter's share in } \\
\text { Parental Property }\end{array}$ & 40 & 45 & 9 & 95 & 11 & 0.592 & 27 & 35 & 14 & 94 & 30 & 0.666 & 36 & 30 & 12 & 95 & 27 & 0.648 \\
\hline $\begin{array}{l}\text { If daughter asking } \\
\text { share in parent's } \\
\text { property that creates } \\
\text { issues }\end{array}$ & 9 & 52 & 23 & 56 & 60 & 0.706 & 17 & 32 & 16 & 64 & 71 & 0.74 & 19 & 42 & 19 & 62 & 58 & 0.698 \\
\hline $\begin{array}{l}\text { Women's power in } \\
\text { decision-making and } \\
\text { own property rights. }\end{array}$ & 8 & 11 & 11 & 42 & 128 & 0.872 & 11 & 10 & 8 & 38 & 133 & 0.872 & 15 & 13 & 4 & 48 & 120 & 0.846 \\
\hline
\end{tabular}

Rank all of the scores, ignoring which group they belong to. The procedure for ranking is as follows: the lowest score gets the lowest rank. If two or more scores are the same then they are "tied". "Tied" scores get the average of the ranks that they would have obtained, had they not been tied. Here are the scores again, now with their ranks: 
Table 8. RII and Rank of Housewives, Member of SHGs and Women Entrepreneurs

\begin{tabular}{|c|c|c|c|c|c|c|c|c|}
\hline Category & RII & Rank & Category & RII & Rank & Category & RII & Rank \\
\hline Housewives & 0.478 & 2 & SHG Member & 0.454 & 1 & Women Entrepreneurs & 0.52 & 3 \\
\hline Housewives & 0.592 & 6.5 & SHG Member & 0.559 & 4 & Women Entrepreneurs & 0.567 & 5 \\
\hline Housewives & 0.595 & 8 & SHG Member & 0.592 & 6.5 & Women Entrepreneurs & 0.617 & 9.5 \\
\hline Housewives & 0.617 & 9.5 & SHG Member & 0.642 & 11 & Women Entrepreneurs & 0.646 & 13 \\
\hline Housewives & 0.652 & 16 & SHG Member & 0.644 & 12 & Women Entrepreneurs & 0.647 & 14 \\
\hline Housewives & 0.655 & 17 & SHG Member & 0.649 & 15 & Women Entrepreneurs & 0.682 & 21 \\
\hline Housewives & 0.679 & 20 & SHG Member & 0.665 & 18 & Women Entrepreneurs & 0.694 & 23 \\
\hline Housewives & 0.688 & 22 & SHG Member & 0.668 & 19 & Women Entrepreneurs & 0.698 & 24 \\
\hline Housewives & 0.706 & 25 & SHG Member & 0.722 & 28.5 & Women Entrepreneurs & 0.716 & 26 \\
\hline Housewives & 0.735 & 31.5 & SHG Member & 0.722 & 28.5 & Women Entrepreneurs & 0.717 & 27 \\
\hline Housewives & 0.736 & 31.5 & SHG Member & 0.74 & 33 & Women Entrepreneurs & 0.726 & 30 \\
\hline Housewives & 0.801 & 35 & SHG Member & 0.786 & 34 & Women Entrepreneurs & 0.807 & 36 \\
\hline Housewives & 0.845 & 40 & SHG Member & 0.845 & 40 & Women Entrepreneurs & 0.82 & 37 \\
\hline Housewives & 0.85 & 42 & SHG Member & 0.859 & 43 & Women Entrepreneurs & 0.825 & 38 \\
\hline Housewives & 0.871 & 45.5 & SHG Member & 0.872 & 45.5 & Women Entrepreneurs & 0.845 & 40 \\
\hline Housewives & 0.888 & 48 & SHG Member & 0.885 & 47 & Women Entrepreneurs & 0.867 & 44 \\
\hline Housewives & 0.914 & 49 & SHG Member & 0.937 & 52.5 & Women Entrepreneurs & 0.922 & 50 \\
\hline Housewives & 0.94 & 54 & SHG Member & 0.938 & 52.5 & Women Entrepreneurs & 0.93 & 51 \\
\hline
\end{tabular}

Hypothesis: H0: There is no significant difference between the issues of TAP towards housewives, members of SHGs and women entrepreneurs.

H1: There is a significant difference between the issues TAP towards housewives, members of SHGs and women entrepreneurs.

Table 8 shows that, "Tci", the total of the ranks for each group. Just add together all of the ranks for each group in turn.

$\mathrm{Tc}_{\mathrm{Hw}}$ (the rank total for the "Housewives" group) is 502.5.

$\mathrm{Tc}_{\text {Shg }}$ (the rank total for the "SHG Members " group) is 491.

$\mathrm{Tc}_{\mathrm{WE}}$ (the rank total for the " Women Entrepreneurs " group) is 491.5 .

$$
\begin{gathered}
\mathrm{H}_{\mathrm{cal}}=\left[12 / \mathrm{N}(\mathrm{N}+1) * \sum \mathrm{Tc}_{\mathrm{i}}^{2} / \mathrm{nc}_{\mathrm{i}}\right]-3(\mathrm{~N}+1) \\
\mathrm{n}_{\mathrm{HW}}=\mathrm{n}_{\mathrm{SHG}}=\mathrm{n}_{\mathrm{WE}}=18 \\
\mathrm{~N}=54, \mathrm{Tc}_{\mathrm{Hw}}=502.5, \mathrm{Tc}_{\mathrm{Shg}}=491, \mathrm{Tc}_{\mathrm{WE}}=491.5 \\
\mathrm{H}_{\text {cal }}=0.0189
\end{gathered}
$$

The degree of freedom is the number of groups minus one. Here we have three groups, and so we have 2 d.f.

Chi-square with $2 \mathrm{df}$ at 5\% 1.o.s is 5.99; Decision Rule: Reject $\mathrm{H} 0$ when $\mathrm{H}_{\text {cal }}>=$ chi-square $2 \mathrm{df}$ at $5 \%$ 1.o.s

Here we accept $\mathrm{H} 0$

There is no significant difference between the issues of TAP towards housewives, members of SHGs and women entrepreneurs. It means that all women categories such as housewives, members of SHGs and Women Entrepreneurs are equally neglected and deprived from resources and faced by discriminatory expectancy of patriarchy. Triangular Attitude of Patriarchy has been working till now everywhere in Indian Society even women entrepreneurs, members of SHGs, and housewives are equally suffered from TAP. There is no area-wise significant differences. Urban and rural women are equally victimized by patriarchic mentality. Therefore the lifelong learning programmes should be launched for all kind of women in both areas. 


\section{Conclusions}

The preceding sub-questions contributed to the researcher's exploration of the central question of this survey study which was the descriptions of the how triangular attitude of patriarchy creates the barriers in lifelong learning of women in urban and rural area. From these sub questions, the researcher has drawn a conclusion under three categories which are Resources, Expectancy and Negligence.

\subsection{Resources}

The issue of Property Right till now was not in prioritization of women due to the heartily respect for their parents and family. Women were more concentrating on education as a resource instead of getting share in parent's property. Real estates of parents were found so problematic to carry and handling them after marriage due to her shifting from parental family to in-laws family. The intensity of needs of women has to acquire in-house training at work place. Women were having high curiosity to improve the quality performance in practices. But the issue is that learning resources at local level was not made available for them. They demanded the in house training to improve their capabilities as per their needs and gear to develop their self-efficacy.

\subsection{Expectancy}

The household has expected girl's earning and day by day this expectation has been increased. In this regard urban people are keeping more aware as compared to rural. Women felt that they could not do the job freely or could not learn openly and frankly because over burden of responsibility of the family and housekeeping work after marriage. The patriarchic expectancy is keeping women in slavery. Caste system was pressurized by patriarchic power structures which did not allow women to marry inter-caste or to live together with someone outside caste. It expects that girl has to marry within the caste otherwise face the violence directly or indirectly as a boycott by fellow member of caste.

\subsection{Negligence}

Women were not treated as equal to male in taskforce with respect to equal payment and equal status at the work place. This sexual discrimination in workforce was found serious issue in this study. Women were not getting equal pay for equal work like men. It was highly crucial and critical issue in private sectors. Women were mostly neglected in Indian society. Such negligence affected direct or indirect to girls' education as a factor of motivation. In family, girls were not involved in decision making even in selection of her life partner. Sexual purity of women was highly sensitive and prestigious matter in Indian male dominated family due to such a mentality of girls were drop-out from school because of early age of marriage.

Women used to hide physical and sexual violence due-to the patriarchic pressure and casual attitude of the so called Society. This concern with protection of female purity and the control and management of female sexuality has led to several customs and social practices.

The research concluded that Triangular Attitude of Patriarchy works everywhere in Indian Society. Women even in entrepreneurs, in SHGs, in home or in urban and rural area they are equally suffered from TAP. Therefore the goal of any lifelong learning community should be to encourage all of its members to reach their highest level of educational attainment without any biases of gender, caste, class, religion and region. Community action should promote socio-economic development and sponsored collaborative workplace learning strategies for small scale enterprises in rural and urban area. For these, lifelong learning policy should adopt the goal on inclusiveness for all the members of the community and can help to reform the attitude of patriarchic society towards women.

\section{Acknowledgements}

This research project was graciously funded by Indian Council of Social Science Research, (Ministry of Human Resource Development), New Delhi. India.

\section{References}

Adnan Enshassi, Peter E. Mayer, Shrif Mohamed \& Fayez EL-Masri. (2007). Perception of Construction Mangers Towards Safety in Palestine. The International Journal of Constructional Management, 41-51. http://dx.doi.org/10.1080/15623599.2007.10773101

Anderson, K. (1997). Gender, status and domestic violence: An Integration of feminist and family violence approaches. Journal of Marriage and the Family(59), 655-669. http://dx.doi.org/10.2307/353952

Biesta, G. (2006). What's the point of lifelong learning if lifelong learning learning has no point? On the democratic deficit of policies for lifelong learning', European Educational Research Journal, 5:169-80. http://dx.doi.org/10.2304/eerj.2006.5.3.169 
Eapen M., M. A. (2010, April 28). Gendering the Twelfth Plan: A Feminist Prospective. Economic \& Political Weekly, XLVII No. 17, pp. 42-49.

Eden, D. (1998). Pygmalion, Goal Setting, and Expectancy: Compatible Ways to Boost Productivity. Academy of Management Review, 13(4), 640.

Hotaling.G.T., \&. S. (1986). An analysis of risk markers in husband to wife violence: The current state of knowledge. Violence and Victims(1), 101-123.

India, S. o. (2010). Statistics on Women in India. New Delhi: National Institute of Public Cooperation \& Development.

Kulkarni, D. (2012, December, Thusday). '24,206 rape cases in India, 7\% in State'. DNA Pune city News Paper., p. 5.

Lang, M., M.P., A., \& Greenstein.T.N. (2005, December 2005). For Women, Breadwinning Can be Dangerous: Gendered Resource Theory and Wife Abuse. Journal of Marriage and Family, 67, 1137-1146. http://dx.doi.org/10.1111/j.1741-3737.2005.00206.x

Lathamma, K. C. (2012, October-December). Indian Journal of Adult education. (D. M. Singh, (Ed.) Gender Inequalities among Agriculture Labourers in Chittor District, 73(4), pp. 5-16.

Mathur, K. (2008, April 26). Review of Women's Studies, Economic \& Political Weekly. Body as space, Body as Site: Bodily Integrity and women's Empowerment in India, p. 55.

McCloskey, L. (1996). Socioeconomic and coercive power within the family. Gender and Society (10), 449-463. http://dx.doi.org/10.1177/089124396010004006

Ming-Te Wang and Jessica Degol. (2013, August Ist). Developmental Review, journal homepage: www.elsevier.com/locate/dr http://dx.doi.org/10.1016/j.dr.2013.08.001. (j. o. Review, Producer, \& Science Director) Retrieved August 14, 2014, from www.elsevier.com/locate/dr: http://dx.doi.org/10.1016/j.dr.2013.08.001

Nandita Kapadia-Kundu, Manisha Khale, Sachin Upadhaye, Deepti Chavan. (2007, September ). Whose Mistake? Gender Roles and Physical Violence among Young Married Women. Economic and Political Weekly, 71.

Oliver, R. (1974, August). Wikipedia Expectancy Theory. (J. o. Research, Producer, \& Wikipedia) Retrieved August 17, 2014, from Wikipedia Expectancy Theory: en.m.wikipedia.org/wiki/Expectancy_theory

Ramu, G. N. (2003). Single and dual erner couples: Economic status and marital power. In S. Rege, \& S. Rege (Ed.), Sociology of Gender: The challenges of sociological knowledge (p. 129). New Delhi, India: Sage Publication Ltd.

Report, I. (2010-2011, December-January). Status of women in India: Problems and concerns. Retrieved November 27, 2012, from www.csss-isla.com: www.csss-isla.com/status of women in India internees report[1].pdf

Sen, A. (2001, October- November). Many faces of Gender Inequality. Frontline, 18(22), pp.4- 5

Shyam Kartik Mishra \& Pradeep Kumar Pandey. (2012). Women Status and Empowerment in India. New Delhi: New Century Publications.

Srivastava, A. (2004). Socio-Economic Status of Women and Gender Disparity: An Inter-district study of Uttar. Pradesh. Chhatrapati Shahu Ji Maharaj University, Kanpur. , DE Economics. 